\title{
( \pm )-Gossypol induces apoptosis and autophagy in head and neck carcinoma cell lines and inhibits the growth of transplanted salivary gland cancer cells in BALB/c mice
}

Monica Benvenuto, Rosanna Mattera, Laura Masuelli, Gloria Taffera, Orlando Andracchio, Ilaria Tresoldi, Paolo Lido, Maria Gabriella Giganti, Justyna Godos, Andrea Modesti \& Roberto Bei

To cite this article: Monica Benvenuto, Rosanna Mattera, Laura Masuelli, Gloria Taffera, Orlando Andracchio, Ilaria Tresoldi, Paolo Lido, Maria Gabriella Giganti, Justyna Godos, Andrea Modesti \& Roberto Bei (2016): ( \pm )-Gossypol induces apoptosis and autophagy in head and neck carcinoma cell lines and inhibits the growth of transplanted salivary gland cancer cells in BALB/c mice, International Journal of Food Sciences and Nutrition, DOI: 10.1080/09637486.2016.1236077

To link to this article: http://dx.doi.org/10.1080/09637486.2016.1236077

Published online: 27 Sep 2016.

Submit your article to this journal

山 Article views: 23

View related articles $[7$

View Crossmark data $₫$ 


\title{
( \pm )-Gossypol induces apoptosis and autophagy in head and neck carcinoma cell lines and inhibits the growth of transplanted salivary gland cancer cells in $B A L B / c$ mice
}

\author{
Monica Benvenuto ${ }^{a}$, Rosanna Mattera ${ }^{a}$, Laura Masuelli ${ }^{b}$, Gloria Taffera ${ }^{a}$, Orlando Andracchio ${ }^{a}$, \\ Ilaria Tresoldi ${ }^{a}$, Paolo Lido ${ }^{c}$, Maria Gabriella Giganti ${ }^{a}$, Justyna Godos ${ }^{d}$, Andrea Modesti ${ }^{a}$ and Roberto Bei ${ }^{a}$ \\ aDepartment of Clinical Sciences and Translational Medicine, Faculty of Medicine, University of Rome "Tor Vergata", Rome, Italy; \\ 'Department of Experimental Medicine, "Sapienza Università di Roma", Rome, Italy; 'Internal Medicine Residency Program, University \\ of Rome "Tor Vergata", Rome, Italy; 'Department of Biomedical and Biotechnological Sciences, University of Catania, Catania, Italy
}

\begin{abstract}
Racemic Gossypol [( \pm )-GOS], composed of both (-)-GOS and (+)-GOS, is a small BH3-mimetic polyphenol derived from cotton seeds. $( \pm)$-GOS has been employed and well tolerated by cancer patients. Head and neck carcinoma (HNC) represents one of the most fatal cancers worldwide, and a significant proportion of HNC expresses high levels of antiapoptotic Bcl-2 proteins. In this study, we demonstrate that ( \pm )-GOS inhibits cell proliferation and induces apoptosis and autophagy of human pharynx, tongue, and salivary gland cancer cell lines and of mouse salivary gland cancer cells (SALTO). ( \pm )-GOS was able to: (a) decrease the ErbB2 protein expression; (b) inhibit the phosphorylation of ERK1/2 and AKT; (c) stimulate p38 and JNK1/2 protein phosphorylation. $( \pm)$-GOS administration was safe in BALB/C mice and it reduced the growth of transplanted SALTO cells in vivo and prolonged mice median survival. Our results suggest the potential role of $( \pm)$-GOS as an antitumor agent in HNC patients.
\end{abstract}

\section{ARTICLE HISTORY}

Received 27 August 2016 Revised 8 September 2016 Accepted 9 September 2016 Published online 27 September 2016

\section{KEYWORDS}

Head and neck cancer; (士)-Gossypol; BH3-mimetic compound; autophagy;

BALB/c mice

\section{Introduction}

Head and neck carcinoma (HNC) represents the seventh most common cancer worldwide, and it mainly involves the larynx, pharynx, oral cavity, and tongue (Ferlay et al. 2015). A significant proportion of head and neck tumors expresses high levels of the antiapoptotic Bcl-2 proteins, which correlates directly with resistance to chemo- and radio-therapy and is associated with the poor clinical outcomes in HNC patients (Xie et al. 1999; Yu et al. 2003; Andrews et al. 2004). The Bcl-2 family proteins (Bcl-2, Bcl-xL, Bcl-W, MCL1, A1/BFL-1) have a structural homology in the Bcl2 homology (BH) 1, 2, 3, and 4 domains. These proteins can interact with $\mathrm{BH} 3$ proteins, such as Bax or Beclin-1, and regulate different intracellular pathways, including apoptosis and autophagy (Maiuri et al. 2007; Sinha \& Levine 2008; Vela et al. 2013). The antiapoptotic protein Bcl-2 binds directly the proapoptotic protein Bax and blocks the activation of the apoptotic pathway. When the ratio between Bax and Bcl-2 increases, there is an increase of the mitochondrial outer membrane permeabilization and the cytosol cytochrome $c$ release and caspase 3 activation (Hata et al. 2015). Autophagy is a type II programmed cell death which activates the lysosomal degradation pathway and is essential for cellular homeostasis. Beclin-1 plays an essential role in autophagy by interacting with different cofactors to form a Beclin-1-Vps 34-Vps 35 core complex (Marquez \& Liang 2012). Furthermore, Beclin-1 has a $\mathrm{BH} 3$ domain at the $\mathrm{N}$-terminus which makes possible its interaction with Bcl-2 which is then inactivated. Beclin-1 dysfunction or increased levels of Bcl-2 can block Beclin-1-dependent autophagy thus contributing to cancer progression (Kang et al. 2011). To overcome these mechanisms, a new class of compounds, called "BH3-mimetics", has been developed. The BH3-mimetics can directly activate apoptosis and autophagy by binding and inhibiting Bcl-2/Bcl-xL (Delbridge \& Strasser 2015).

Racemic Gossypol (( \pm )-GOS; ( \pm )-2,2' -bis(8-Formyl1,6,7-trihydroxy-5-isopropyl-3-methylnaphthalene), composed of both (-)-GOS and (+)-GOS, is a naturally occurring polyphenolic yellow pigment present in cotton-seeds and cotton plants-derived products, used

CONTACT Roberto Bei $\otimes$ bei@med.uniroma2.it E Department of Clinical Sciences and Translational Medicine, Faculty of Medicine, University of Rome

"Tor Vergata", Via Montpellier 1, 00133, Rome, Italy

(C) 2016 Informa UK Limited, trading as Taylor \& Francis Group 
in herbal medicines in China (Huang et al. 2006). Cotton is produced worldwide and its major products are cotton fibers, cotton-seed oil, and cotton-seed proteins. Gossypol is the principal component of the pigment glands, mainly found not only in cotton-seeds but also in bark of plant roots, leaves, seed hulls, and flowers. Gossypol constitutes $20-40 \%$ of the gland weight and accounts for $0.4-1.7 \%$ of the whole kernel of cotton-seeds. The amount of gossypol is dependent from the species and variety of cotton plant, soil and climatic conditions, water supply, agriculture techniques, and composition of fertilizers used. Cotton-seed oil and proteins are extracted from the cotton-seeds gland as a by-product of cotton fibers production, and the gossypol content in oil is influenced by the oilseed processing (Wang et al. 2009). It is estimated that from $1 \mathrm{~kg}$ of fibers the plant produces about $1.65 \mathrm{~kg}$ of seeds, which can be employed for the production of cottonseed oil and cotton-seed meal as food for human consumption and animals feed (Sunilkumar et al. 2006). However, food sources containing gossypol has limited use because gossypol possesses anti-proliferative activity (Wang et al. 2009). Indeed, the US Food and Drug Administration (FDA 1974) specifies limits of $450 \mathrm{ppm}$ of free-gossypol in cotton-seed protein products for human use, and the Protein Advisory Group of the United Nations Food and Agriculture and World Health Organizations (FAO/WHO/UNICEF 1972) specify limits of $600 \mathrm{ppm}$ of free gossypol and 12,000 ppm of total gossypol in food products.

On the other hand, several studies have highlighted the antitumoral activity of gossypol purified from cotton plant. Indeed, the in vitro and in vivo anti-proliferative effect of gossypol in various types of cancer, including breast, ovary, cervix, uterus, adrenals, pancreas, colon, and head and neck, has been demonstrated (Huang et al. 2006). Gossypol is a small BH3-mimetic compound, which is able to inhibit Bcl-2/Bcl-xL. Gossypol can block the interaction between $\mathrm{Bcl}-2 / \mathrm{Bcl}-\mathrm{xL}$ and Beclin-1 or Bax, thus inducing apoptosis and autophagy (Meng et al. 2008; Lian et al. 2010). Gossypol was also employed in phase I/II clinical trials, as single agent and also in combination with conventional therapies, for the treatment of different types of cancer and it was well tolerated (Stein et al. 1992; Flack et al. 1993; van Poznak et al. 2001; Sonpavde et al. 2012; Schelman et al. 2014).

A phase II study employing gossypol, in combination with docetaxel, for the treatment of head and neck squamous cell carcinoma has recently been completed. However, combined therapy with docetaxel and gossypol failed to provide an increase in clinical benefit for these HNC patients (Swiecicki et al. 2016).

In our study, we explored the in vitro and in vivo $( \pm)$-GOS antitumor activity in HNC. We demonstrate that $( \pm)$-GOS inhibits cell proliferation and induces apoptosis and autophagy of human pharynx $(\mathrm{FaDu})$, tongue (CAL-27), and salivary gland (A-253) cancer cells and of mouse salivary gland cancer cells (SALTO), which were established from salivary adenocarcinoma arising in BALB-neuT transgenic male mice. $( \pm$ )-GOS was able to: (a) decrease the ErbB2 protein expression; (b) inhibit the phosphorylation of ERK1/2 and AKT; (c) stimulate $\mathrm{p} 38$ and JNK1/2 phosphorylation. We demonstrated that $( \pm)$-GOS administration was safe in $\mathrm{BALB} / \mathrm{c}$ mice and it reduced the growth of mouse-transplanted SALTO cells and prolonged mice median survival.

Overall, our results suggest the potential role of the BH3-mimetic compound $( \pm)$-GOS as an antitumor agent in HNC patients.

\section{Materials and methods}

\section{Reagents}

DMSO, ( \pm )-Gossypol (GOS), and Sulforhodamine B (SRB) were purchased from Sigma Aldrich (Milano, Italy). Antibodies against AKT, phospho-AKT, Bax, Bcl-2, JNK/SAPK1, JNK/SAPK (pT183/pY185), p38a/ SAPK2a, p38 MAPK (pT180/pY182) were obtained from BD Pharmingen (BD Biosciences, San Jose, CA). Antibodies against ERK1/2 (C-14), phospho-ERK (E4), PARP-1, and p53 (DO-1) were obtained from Santa Cruz Biotechnology (Dallas, TX). Antibody against LC3 was obtained from Novus Biologicals (Littleton, CO). Antibodies against Beclin-1 were obtained from Abcam (Cambridge, UK). The anti-caspase 9 (C9), anti-caspase 8 (1C12), and anti-cleaved caspase 3 (Asp175) antibodies were purchased from Cell Signaling Technology (Danvers, MA). Anti-ErbB2 and anti-EGFR antisera were provided by Dr. M.H. Kraus (University of Alabama, Birmingham, AL). Rabbit polyclonal anti-Actin was obtained from Sigma-Aldrich. Goat anti-mouse or anti-rabbit IgG peroxidase-conjugated secondary antibodies were purchased from Sigma-Aldrich.

\section{Cell lines and treatments}

Cell lines derived from carcinoma of the tongue (CAL-27) or pharynx (FaDu) or salivary gland (A253) were maintained in RPMI containing $10 \%$ fetal bovine serum, $100 \mathrm{U} / \mathrm{ml}$ penicillin, and $100 \mu \mathrm{g} / \mathrm{ml}$ 
streptomycin. For treatments, cells were incubated for the indicated times in the presence of GOS (dose range $1.25-80 \mu \mathrm{M}$ ) or vehicle control $(\mathrm{DMSO} \leq 0.1 \%)$. Neu-overexpressing salivary gland cancer cells $\left(\mathrm{H}-2^{\mathrm{d}}\right)$ (SALTO) were kindly provided by Prof. F. Cavallo (University of Torino) and Prof. P.L. Lollini and Prof. P. Nanni (University of Bologna) and maintained in DMEM containing 20\% fetal bovine serum, $100 \mathrm{U} / \mathrm{ml}$ penicillin, and $100 \mu \mathrm{g} / \mathrm{ml}$ streptomycin. SALTO cells were established from salivary gland adenocarcinoma arising in BALB-neuT transgenic male mice hemizygous for p53 ${ }^{172 \mathrm{R}-\mathrm{H}}$ transgene driven by the whey acidic protein promoter (Pannellini et al. 2006).

\section{Sulforhodamine B (SRB) assay}

Cells were seeded at $5 \times 10^{3} /$ well in 96-well plates and incubated at $37^{\circ} \mathrm{C}$ to allow cell attachment. After $24 \mathrm{~h}$, the medium was changed, and the cells were treated with GOS or DMSO and incubated for 24,48 , and $72 \mathrm{~h}$, at concentrations of $1.25-80 \mu \mathrm{M}$. The cells were then fixed with cold trichloroacetic acid (final concentration $10 \%$ ) for $1 \mathrm{~h}$ at $4{ }^{\circ} \mathrm{C}$. After four washes with distilled water, the plates were air-dried and stained for $30 \mathrm{~min}$ with $0.4 \%$ (wt/vol) SRB in $1 \%$ acetic acid. After four washes with $1 \%$ acetic acid to remove the unbound dye, the plates were air-dried, and cellbound SRB was dissolved with $200 \mu \mathrm{l} /$ well of $10-\mathrm{mM}$ unbuffered Tris base solution. The optical density (O.D.) of the samples was determined at $540 \mathrm{~nm}$ with a spectrophotometric plate reader. The percentage survival of the cultures treated with GOS was calculated by normalizing their O.D. values to those of control cultures treated with DMSO (Masuelli et al. 2014a). The experiments were performed in triplicate and repeated three times.

\section{FACS analysis}

Asynchronized, log-phase growing cells $(60 \%$ confluent, approximately $2.5 \times 10^{5} /$ well in 6 -well plates) were treated with GOS or DMSO in complete culture medium. After $48 \mathrm{~h}$, adherent as well as suspended cells were harvested, centrifuged at $1500 \mathrm{rpm}$ for $10 \mathrm{~min}$ and washed twice with cold phosphate-buffered saline (PBS). The cell pellets were resuspended in $70 \%$ ethanol and incubated for $1 \mathrm{~h}$ at $-20^{\circ} \mathrm{C}$. The cells were then washed twice with cold PBS, centrifuged at $1500 \mathrm{rpm}$ for $10 \mathrm{~min}$, incubated for $1 \mathrm{~h}$ in the dark with propidium iodide $(25 \mu \mathrm{g} / \mathrm{ml}$ final concentration in $0.1 \%$ citrate and $0.1 \%$ Triton X-100), and analyzed by flow cytometry using a FACSCalibur cytometer with CellQuest Pro 5.2 software (BD Biosciences, San Jose, CA) (Masuelli et al. 2012a).

\section{Preparation of cell lysates and Western blotting}

Approximately $1 \times 10^{6}$ cells were seeded in $100-\mathrm{mm}$ tissue culture dishes $24 \mathrm{~h}$ prior to the addition of $20 \mu \mathrm{M}$ GOS or vehicle control. After $24 \mathrm{~h}$ (for $\mathrm{FaDu}$, CAL-27, and A-253) and $48 \mathrm{~h}$ (for SALTO) of incubation, the cells were harvested, washed twice with cold PBS, and lysed in RIPA lysis buffer (Triton X-100 1\%, SDS $0.1 \%, \mathrm{NaCl} 200 \mathrm{mM}$, Tris $\mathrm{HCl} 50 \mathrm{mM}$ pH 7.5, PMSF $1 \mathrm{mM}$, and $\mathrm{NaOV} 1 \mathrm{mM}$ ) (Benvenuto et al. 2015; Frajese et al. 2016). After $30 \mathrm{~min}$ at $4{ }^{\circ} \mathrm{C}$, the mixtures were centrifuged at $12,000 \mathrm{~g}$ for $15 \mathrm{~min}$, and the supernatants were analyzed by Western blotting. For immunoblotting analysis, $50 \mu \mathrm{g}$ of cell lysates were resolved in $10 \%$ SDS-PAGE and then transferred to nitrocellulose membranes. After blocking, the membranes were incubated with specific primary antibodies at $1-2 \mu \mathrm{g} / \mathrm{ml}$ concentrations overnight at $4{ }^{\circ} \mathrm{C}$. After being washed, the filters were incubated with goat anti-mouse or anti-rabbit IgG, peroxidase-conjugated antibodies and developed by chemiluminescence as previously described (Masuelli et al. 2012b). A densitometric analysis of autoradiographic bands was performed with ImageJ $1.42 \mathrm{q}$ software (National Institutes of Health, Bethesda, MD) after blot scanning.

\section{Transmission electron microscopy}

Ultrastructural analyses were performed on CAL-27 cells treated with $10 \mu \mathrm{M}$ GOS or with DMSO for $24 \mathrm{~h}$. After treatment, the cells were fixed in $2.5 \%$ glutaraldehyde in PBS pH 7.4, and the samples were processed for transmission electron microscopy following routine procedures (Masuelli et al. 2003).

\section{In vivo treatment of $B A L B / C$ mice with GOS}

$\mathrm{BALB} / c$ mice were subcutaneously injected in the right flank with a $0.2 \mathrm{ml}$ suspension containing $1 \times 10^{6}$ SALTO cells in phosphate-buffered saline (PBS). Groups of $\mathrm{BALB} / \mathrm{c}$ mice (five mice per GOS-group and seven mice per control (CTR)-group) were treated weekly, starting three weeks after SALTO transplantation, with an intratumoral injection of $15 \mathrm{mg} / \mathrm{kg}$ of GOS administered with corn oil $(50 \mu \mathrm{l})$ as vehicle for two weeks and then with oral administration of $15 \mathrm{mg} / \mathrm{kg}$ of GOS administered with corn oil $(50 \mu \mathrm{l})$ three times a week. The control group (CTR) was treated with corn oil employing the same protocol of 
GOS. Mice were sacrificed at the first signs of distress. All experiments were approved by the Institutional Animal Care and Use Committee (IACUC) and carried out according to Italian rules (D.L.vo 116/92; CE. 609/86). The work was conducted with the formal approval of the local human subject or animal care committees (institutional and national), and the animal experiments have been registered as legislation requires (Authorization from Ministry of Health $\mathrm{n}^{\circ}$ $187 / 2016-P R)$. A veterinary surgeon was present during the experiments. Animal care, before and after the experiments, was carried out only by trained personnel. Mice were bred under pathogen-free conditions in the animal facilities of Tor Vergata University and handled in compliance with European Union and institutional standards for animal research (Masuelli et al. 2010, 2014b).

\section{Analysis of antitumor activity in vivo}

Tumor growth was monitored weekly until tumorbearing mice were sacrificed at the first signs of distress or when their tumors exceeded $20 \mathrm{~mm}$ in width (Masuelli et al. 2016). Tumors were measured with a caliper in two dimensions, and the volumes were calculated by using the following formula: (width ${ }^{2} \times$ length)/2 (Bei et al. 1998).

\section{Statistical analysis}

Data distribution of cell survival and the FACS analyses were preliminarily verified by Kolmogorov-Smirnov test, and data sets were analyzed by one-way analysis of variance (ANOVA) followed by Newman-Keuls test. Differences in the intensity of immunoreactive bands were evaluated by a two-tailed Student's $t$-test. Values with $p \leq .05$ were considered significant. Survival curves and tumor volumes were estimated using the Kaplan-Meier method and compared with a log-rank test (Mantel-Cox). Differences in tumor volumes were regarded as significant when the $p$ value was $\leq .05$ (Masuelli et al. 2010).

\section{Results}

\section{Inhibition of human and mouse HNC cell survival by GOS}

The survival of tongue (CAL-27), pharynx $(\mathrm{FaDu})$, and salivary gland (A-253) carcinoma cell lines was evaluated by the SRB assay after exposure to increasing concentrations $(1.25 \mu \mathrm{M}, 2.5 \mu \mathrm{M}, 5 \mu \mathrm{M}, 10 \mu \mathrm{M}$, $20 \mu \mathrm{M}, 40 \mu \mathrm{M}$, and $80 \mu \mathrm{M}$ ) of GOS or vehicle control
(DMSO), for $24 \mathrm{~h}, 48 \mathrm{~h}$, and $72 \mathrm{~h}$. Experiments were also performed employing SALTO cells to establish whether this mouse cancer cell line was susceptible to the in vitro antitumor activity of GOS and would thus be suitable for determining the in vivo antitumor effects of GOS following SALTO cells transplantation into $\mathrm{BALB} / \mathrm{c}$ mice.

The effect of GOS on cell proliferation was doseand time-dependent and was significant compared to the control at doses from 5 to $80 \mu \mathrm{M}$ in $\mathrm{FaDu}$, CAL27 , and A-253 cell lines after $48 \mathrm{~h}(p<.001)$ and $72 \mathrm{~h}$ $(p<.001)$. After $24 \mathrm{~h}$, GOS significantly decreased cell survival at doses from 10 to $80 \mu \mathrm{M}$ in $\mathrm{FaDu}, \mathrm{CAL}-27$, and A-253 cells $(p<.001)$ and at $5 \mu \mathrm{M}$ in CAL-27 and A-253 cell lines $(p<.05)$. GOS significantly reduced SALTO cell survival at 20,40 , and $80 \mu \mathrm{M}$ after 24 $(p<.05$ at $20 \mu \mathrm{M} ; p<.001$ at $40-80 \mu \mathrm{M}), 48(p<.001)$ and $72 \mathrm{~h}(p<.001)$ and at $10 \mu \mathrm{M}$ only after $72 \mathrm{~h}$ of treatment $(p<.05)$. The mean results of three independent experiments are reported in Figure 1.

The concentration of compound that inhibits 50\% of cell growth (IC50) was also determined. The concentrations of GOS required to reduce cell survival by $50 \%$ after 48 and $72 \mathrm{~h}$ were 9.74 and $4.75 \mu \mathrm{M}$ for $\mathrm{FaDu}$, respectively; 12.72 and $5.02 \mu \mathrm{M}$ for CAL-27, respectively; 18.56 and $6.57 \mu \mathrm{M}$ for A-253, respectively; 87.05 and $23.27 \mu \mathrm{M}$ for SALTO cells, respectively (Table 1).

\section{Effect of GOS on cell cycle distribution in HNC cell lines}

To evaluate the effect of GOS on cell cycle distribution, FACS analysis of DNA content was performed on HNC cell lines treated with increasing doses of GOS $(5-40 \mu \mathrm{M})$ for $48 \mathrm{~h}$. DMSO was used as the vehicle control.

GOS treatment at the highest doses $(20-40 \mu \mathrm{M})$ increased the percentage of SALTO cells in the subG1 phase and exerted the same effect on human CAL27 and A-253 cells at $10-20-40 \mu \mathrm{M}$ and on FaDu cells at all doses tested. The increase in the percentage of cells in sub-G1 phase was associated with a decrease in the percentage of cells in G0/G1, S, and G2/M phases in FaDu, CAL-27, and A-253 cells and with a reduction in the percentage of cells in $S$ and $G 2 / M$ phases in SALTO cells. The mean results of three independent experiments are reported in Table 2.

\section{GOS mediates apoptosis in HNC cells}

To corroborate the effect of GOS in mediating apoptosis, as seen by the GOS-mediated increase of the 


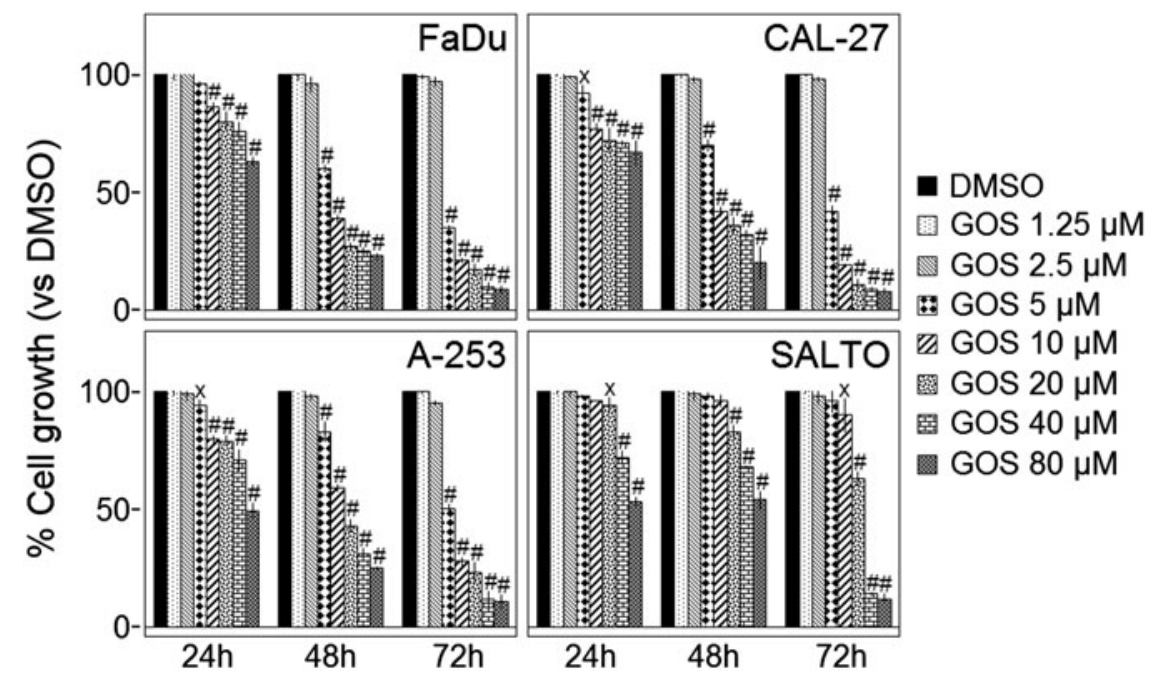

Figure 1. Effect of GOS on HNC cell lines survival. The survival of human (FaDu, CAL-27, A-253) and mouse (SALTO) HNC cell lines were assessed by the SRB assay after 24,48 , and $72 \mathrm{~h}$ of treatment with DMSO or GOS. The percentage of surviving cells treated with GOS or the vehicle control was calculated by normalizing the O.D. (Optical Density) value to that of the untreated control cultures. The results are expressed as the means \pm SD of three independent experiments performed in triplicate $(\times p \leq .05$, \#p $\leq .001$ compared with the cultures treated with DMSO).

Table 1. GOS concentrations required for $50 \%$ inhibition of HNC cell lines survival (IC50).

\begin{tabular}{lcr}
\hline HNC cell lines & GOS treatment (hours) & IC50 $(\mu \mathrm{M}) \pm$ SD \\
\hline FaDu & 48 & $9.74 \pm 0.32$ \\
& 72 & $4.75 \pm 0.08$ \\
CAL-27 & 48 & $12.72 \pm 0.57$ \\
& 72 & $5.02 \pm 0.13$ \\
A-253 & 48 & $18.56 \pm 0.54$ \\
& 72 & $6.57 \pm 0.64$ \\
SALTO & 48 & $87.05 \pm 9.22$ \\
& 72 & $23.27 \pm 1.16$ \\
\hline
\end{tabular}

percentage of cells in sub-G1 phase, the expression and activation of different signal transduction molecules involved in the apoptotic process were evaluated by Western blotting (Figure 2). HNC cell lines were treated with $20 \mu \mathrm{M}$ GOS or DMSO for $24(\mathrm{FaDu}$, CAL-27, and A-253) or $48 \mathrm{~h}$ (SALTO). After incubation, cell lysates were resolved in 10-12\% SDS-PAGE, transferred to nitrocellulose membranes and incubated with specific antibodies.

GOS increased the $\mathrm{Bax} / \mathrm{Bcl}-2$ expression ratio compared to controls (FaDu: $p=.003$; CAL-27: $p=.003$; A-253: $p=.007)$ and decreased the Bcl-2 levels in all human HNC cells (FaDu: $p=.002$; CAL-27: $p=.006$; A-253: $p=.002$ ).

In addition, a decreased p53 expression was observed in $\mathrm{FaDu}(p=.007)$ and CAL-27 $(p=.003)$ cells after GOS treatment. A-253 were shown to lack p53 (Reiss et al. 1992; Courtois et al. 1997).

In order to determine which apoptotic pathway was activated after GOS treatment, the expression and cleavage of procaspases 9,8 , and 3 were analyzed by Western blotting in human HNC cell lines (Figure 2, panel A). Treatment with GOS induced a significant decrease of procaspase 9 expression level in $\mathrm{FaDu}$ $(p=.007)$, CAL-27 $(p=.002)$ and A-253 ( $p=.003)$ cells. In addition, GOS induced the proteolytic cleavage of procaspase 9 into the active fragments in $\mathrm{FaDu}$ and CAL-27, as indicated by the appearance of the active fragments of $37,35 \mathrm{kD}$. These results indicate the activation of the intrinsic pathway of apoptosis by GOS in human HNC cell lines. In addition, GOS was able to induce activation of the extrinsic pathway of apoptosis, as demonstrated by the proteolytic cleavage of caspase 8 into the active fragments p43/41 in human HNC cell lines.

Activated caspases 8 and 9 are able to cleave and activate caspase 3 , that induces the proteolytic inactivation of PARP-1, a DNA repair enzyme. Our results showed that GOS mediated the proteolytic cleavage of caspase 3 into the activated fragments p19 and p17 in $\mathrm{FaDu}, \mathrm{CAL}-27$, and A-253 cells. In addition, PARP-1 GOS-mediated proteolytic cleavage was observed in human HNC cell lines (FaDu: $p=.002$; CAL-27: $p=.005$; A-253: $p=.002$ ). Activation of apoptosis was also demonstrated in SALTO cells by GOS-mediated cleavage of caspase 3 and increase of the Bax/Bcl-2 ratio $(p=.011)$ (Figure 2, panel B).

\section{GOS activates the autophagic flux in HNC cells}

The formation of an autophagosome is the marker of autophagy. The activation of the autophagic process can be detected by the conversion of light chain 3 (LC3)-I in LC3-II, because the amount of LC3-II 
Table 2. Effects of GOS on cell cycle distribution. FACS analysis of DNA content was performed on asynchronized log phase growing HNC cells treated for $48 \mathrm{~h}$ with DMSO or GOS.

\begin{tabular}{|c|c|c|c|c|c|c|c|c|c|}
\hline & $\mu \mathrm{M}$ & sub-G1 ${ }^{a}$ & $p$ Value & G0/G1 & $p$ Value & $S$ & $p$ Value & G2/M & $p$ Value \\
\hline \multirow[t]{5}{*}{$\mathrm{FaDu}$} & DMSO & $2.83 \pm 0.10$ & & $54.16 \pm 1.65$ & & $10.52 \pm 0.25$ & & $32.99 \pm 1.75$ & \\
\hline & GOS 5 & $14.79 \pm 3.15$ & $<.01$ & $57.40 \pm 3.10$ & NS & $11.11 \pm 0.17$ & NS & $17.66 \pm 0.11$ & $<.001$ \\
\hline & GOS 10 & $25.98 \pm 1.77$ & $<.001$ & $53.81 \pm 0.25$ & NS & $9.79 \pm 0.17$ & NS & $11.42 \pm 2.11$ & $<.001$ \\
\hline & GOS 20 & $53.04 \pm 1.98$ & $<.001$ & $36.81 \pm 1.20$ & $<.001$ & $6.75 \pm 0.28$ & $<.001$ & $4.33 \pm 0.58$ & $<.001$ \\
\hline & GOS 40 & $77.84 \pm 3.96$ & $<.001$ & $16.71 \pm 1.99$ & $<.001$ & $2.00 \pm 0.92$ & $<.001$ & $3.78 \pm 1.12$ & $<.001$ \\
\hline \multirow[t]{5}{*}{ CAL-27 } & DMSO & $2.66 \pm 0.16$ & & $59.95 \pm 1.65$ & & $14.73 \pm 0.26$ & & $23.03 \pm 2.03$ & \\
\hline & GOS 5 & $5.97 \pm 3.36$ & NS & $62.50 \pm 4.24$ & NS & $12.67 \pm 1.68$ & NS & $19.27 \pm 5.93$ & NS \\
\hline & GOS 10 & $17.33 \pm 2.23$ & $<.05$ & $60.19 \pm 4.71$ & NS & $13.45 \pm 0.37$ & NS & $9.47 \pm 2.26$ & $<.05$ \\
\hline & GOS 20 & $76.89 \pm 1.99$ & $<.001$ & $22.01 \pm 0.54$ & $<.001$ & $0.87 \pm 0.54$ & $<.001$ & $0.79 \pm 0.82$ & $<.01$ \\
\hline & GOS 40 & $76.40 \pm 7.16$ & $<.001$ & $17.83 \pm 5.03$ & $<.001$ & $3.37 \pm 1.03$ & $<.001$ & $2.69 \pm 1.01$ & $<.01$ \\
\hline \multirow[t]{5}{*}{$A-253$} & DMSO & $11.65 \pm 0.18$ & & $57.68 \pm 1.35$ & & $11.35 \pm 0.37$ & & $19.78 \pm 0.76$ & \\
\hline & GOS 5 & $15.42 \pm 0.25$ & NS & $53.75 \pm 2.61$ & NS & $11.37 \pm 1.10$ & NS & $19.82 \pm 1.92$ & NS \\
\hline & GOS 10 & $19.67 \pm 1.49$ & $<.05$ & $53.17 \pm 4.14$ & NS & $12.11 \pm 2.01$ & NS & $15.41 \pm 0.59$ & $<.05$ \\
\hline & GOS 20 & $41.49 \pm 0.52$ & $<.001$ & $42.57 \pm 0.28$ & $<.01$ & $7.87 \pm 0.18$ & $<.05$ & $8.55 \pm 1.00$ & $<.001$ \\
\hline & GOS 40 & $77.00 \pm 4.36$ & $<.001$ & $17.39 \pm 3.01$ & $<.001$ & $2.73 \pm 0.52$ & $<.01$ & $3.07 \pm 0.87$ & $<.001$ \\
\hline \multirow[t]{5}{*}{ SALTO } & DMSO & $3.76 \pm 0.49$ & & $36.49 \pm 1.62$ & & $7.11 \pm 0.46$ & & $52.95 \pm 0.60$ & \\
\hline & GOS 5 & $3.60 \pm 0.57$ & NS & $37.99 \pm 1.38$ & NS & $7.34 \pm 0.52$ & NS & $51.40 \pm 1.23$ & NS \\
\hline & GOS 10 & $3.21 \pm 0.41$ & NS & $37.87 \pm 0.33$ & NS & $7.12 \pm 0.52$ & NS & $52.09 \pm 0.45$ & NS \\
\hline & GOS 20 & $6.92 \pm 0.55$ & $<.05$ & $39.83 \pm 0.96$ & NS & $5.74 \pm 0.76$ & NS & $47.33 \pm 0.01$ & $<.01$ \\
\hline & GOS 40 & $42.43 \pm 1.84$ & $<.001$ & $39.34 \pm 0.17$ & NS & $4.03 \pm 1.07$ & $<.05$ & $14.47 \pm 0.72$ & $<.001$ \\
\hline
\end{tabular}

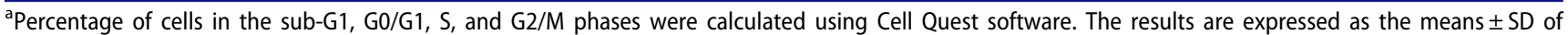
three independent experiments performed in triplicate. GOS was used in the range 5-40 $\mu \mathrm{M}$. Statistical significance of the effects obtained with GOS was calculated versus those obtained in DMSO-treated cells. NS: not significant.

correlates with the number of autophagosomes (Mizushima \& Yoshimori 2007). To evaluate the effect of GOS on the induction of the autophagic flux, HNC cells were treated with GOS $(20 \mu \mathrm{M})$ or DMSO for 24 (FaDu, CAL-27, and A-253) or $48 \mathrm{~h}$ (SALTO) (Figure 3, panel A). Our results showed that GOS induced the conversion of LC3-I into LC3-II, as demonstrated by the significant increase in the amount of LC3-II (FaDu: $p=.0004 ;$ CAL-27: $p=.006 ; \mathrm{A}-253$ : $p=.005$; SALTO: $p=.017)$ and the significant decrease of LC3-I expression (FaDu: $p=.002$; CAL-27: $p=.005$; A-253: $p=.0009)$ in GOS-treated cells compared to DMSO-treated cultures.

To further investigate the mechanism of autophagy induced by GOS, we evaluated the expression of Beclin-1, because GOS is a BH3-mimetic compound which is able to interrupt the interaction between Bcl2 and Beclin-1, thus activating Beclin-1-dependent autophagy (Marquez \& Liang 2012). Our results showed that GOS significantly increased the expression of Beclin-1 in CAL-27 $(p=.001), \quad \mathrm{A}-253$ $(p=.0008)$, and SALTO $(p=.0002)$ cells, while the expression of Beclin-1 did not change after GOS treatment in FaDu cells.

The induction of the autophagic flux was confirmed employing transmission electron microscopy using the CAL-27 cell line (Barth et al. 2010). CAL-27 cells were treated with GOS at the concentration of $10 \mu \mathrm{M}$ for $24 \mathrm{~h}$ or with DMSO. No autophagic vacuoles were seen in DMSO-treated cells. Conversely, GOS-treated cells showed the presence of cytoplasmatic autophagic vacuoles surrounded by double membrane and containing cytoplasm and organelles (Figure 3, panel B).

These results indicated that GOS was able to induce activation of the autophagic flux in HNC cells.

\section{GOS impairs the expression and activation of pro- survival signaling pathway molecules in HNC cells}

Different signaling transduction pathways are involved in cell growth, autophagy, and apoptosis. Abnormal expression and activation of ErbB receptors and downstream signaling pathways are implicated in the development and progression of head and neck cancer (Bei et al. 2001; Sacco \& Worden 2016). To evaluate whether GOS alters the expression of EGFR/ErbB2 and the expression and activation of extracellular signal-regulated kinases (ERK1/2), c-Jun NH2-terminal kinases (JNK1/2), and p38-MAPKs (p38-MAPK $\alpha$ ) (Wada \& Penninger 2004), Western blotting analysis was performed after treating cells with GOS $(20 \mu \mathrm{M})$ or DMSO for 24 (FaDu, CAL-27 and A-253) or $48 \mathrm{~h}$ (SALTO). GOS treatment significantly reduced EGFR expression compared to DMSO-treated cells in FaDu cells $(p=.002)$, while GOS treatment did not change EGFR expression in the other cell lines. Conversely, all GOS-treated cell lines showed a reduced expression of ErbB2 compared to DMSO-treated cells $(p=.008$ for $\mathrm{FaDu}$; $p=.048$ for CAL-27; $p=.013$ for A-253 and SALTO cells) (Figure 4).

The levels of phosphorylated ERK1 (p-ERK1) and ERK2 (p-ERK2) proteins, as well as p-p38-MAPK $\alpha$ 
(A)

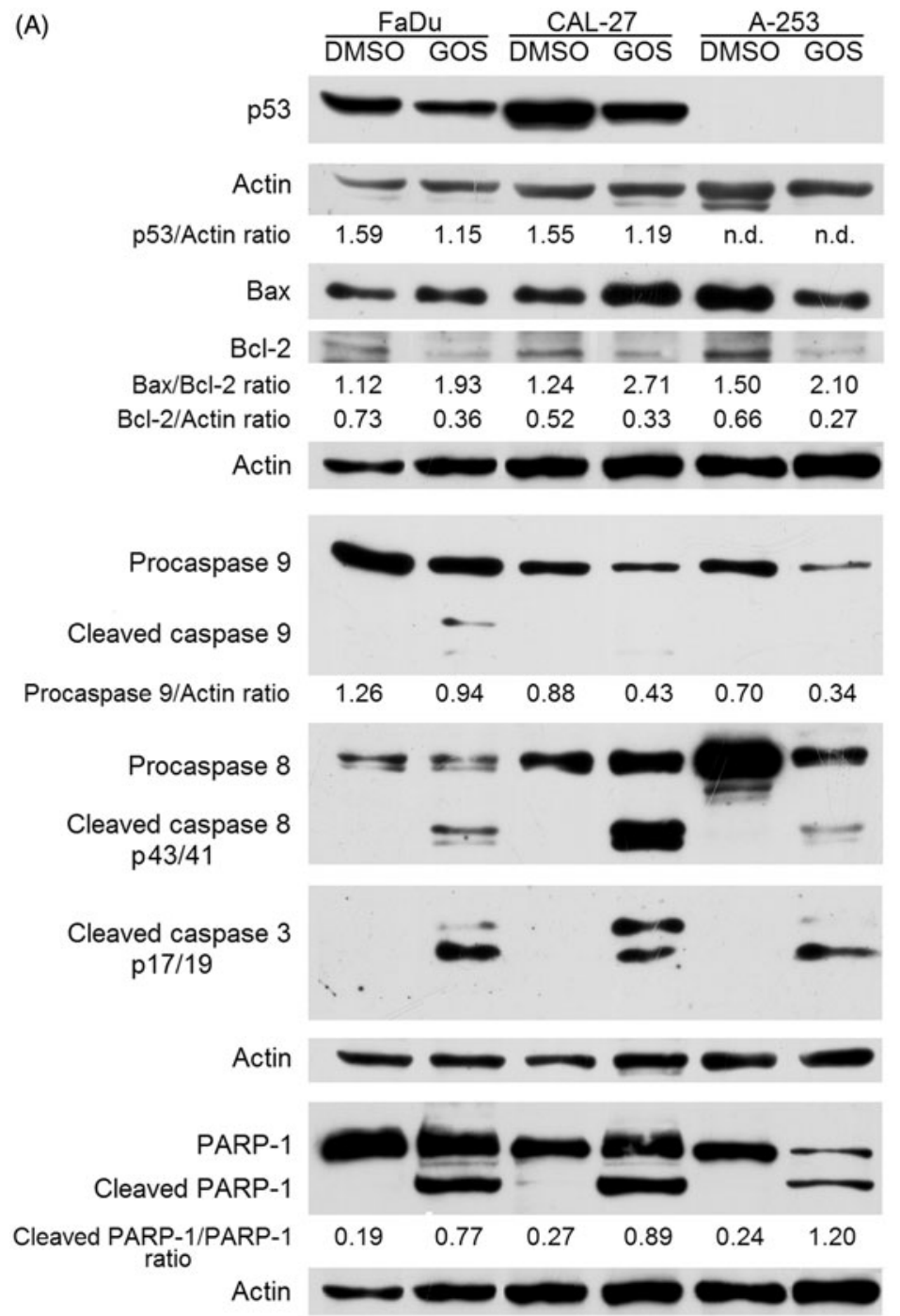

(B)
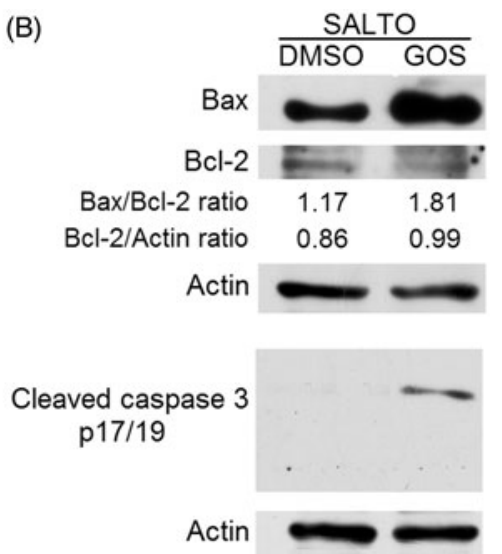

Figure 2. Effect of GOS on molecules involved in apoptosis. Panel A: The expression of p53, Bax, Bcl-2, procaspases (9-8), cleaved caspases (9-8-3), and PARP-1 cleavage was assessed by Western blotting in human HNC cell lines treated with GOS (20 $\mu$ M) or DMSO for $24 \mathrm{~h}$. Panel B: The expression of Bax, Bcl-2, and cleaved caspase 3 was assessed by Western blotting in SALTO cell line treated with GOS $(20 \mu \mathrm{M})$ or DMSO for $48 \mathrm{~h}$. Actin was used as an internal control. The intensity of the bands obtained in two independent experiments was quantified using ImageJ software after blot scanning, and the densitometric ratios between p53 and actin, between Bax and $\mathrm{Bcl}-2$, between $\mathrm{Bcl}-2$ and actin, between procaspase 9 and actin, and between cleaved and full-length PARP-1 are reported. n.d.: not detected.

protein and $\mathrm{p}$-JNK1 and $\mathrm{p}$-JNK2 proteins, were compared with the total ERK, p38, and JNK1/2 protein levels, respectively. Our results showed that GOS significantly decreased ERK1 and ERK2 phosphorylation in FaDu (p-ERK1: $p=.0002$; p-ERK2: $p=.0001$ ), CAL-27 (p-ERK1: $p=.0009 ; \mathrm{p}-\mathrm{ERK} 2: p=.027), \mathrm{A}-253$ (p-ERK1: $p=.001 ; \mathrm{p}$-ERK2: $p<.001$ ), and SALTO (pERK1: $p=.0007$; $p$-ERK2: $p<.001)$ cells. GOS significantly increased p38-MAPK $\alpha$ phosphorylation in all cell lines $(p=.004$ for FaDu; $p=.0002$ for CAL-27; $p=.002$ for A-253; $p=.003$ for SALTO cells). In addition, GOS-treated FaDu, CAL-27, and A-253 cells showed an increased expression of phosphorylated JNK1 and JNK2 (FaDu: $p=.001$ for $p$-JNK1 and
p-JNK2; CAL-27: $p=.04$ for p-JNK1, $p=.03$ for p-JNK2; A-253: $p=.002$ for JNK1, $p=.001$ for JNK2). Conversely, GOS did not modify the expression of p-JNK1/2 in SALTO cells (Figure 4).

Finally, we evaluated whether GOS treatment inhibited the protein expression of the pro-survival kinase AKT, which promotes tumor cells growth. GOS did not alter the basal protein expression levels of AKT, but significantly decreased the phosphorylated AKT (p-AKT) protein levels compared with DMSO-treated cells in $\mathrm{FaDu}(p=.016), \mathrm{CAL}-27 \quad(p=.001)$ and SALTO $(p=.007)$ cells. Conversely, in A-253 cells, GOS significantly decreased only the basal protein expression level of AKT $(p=.019)$ (Figure 4). 
(B)

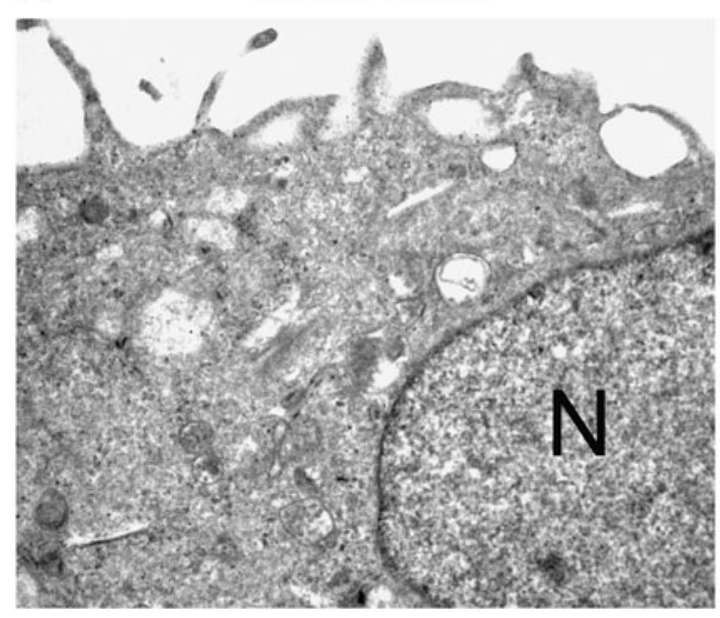

CAL-27 DMSO
(A)
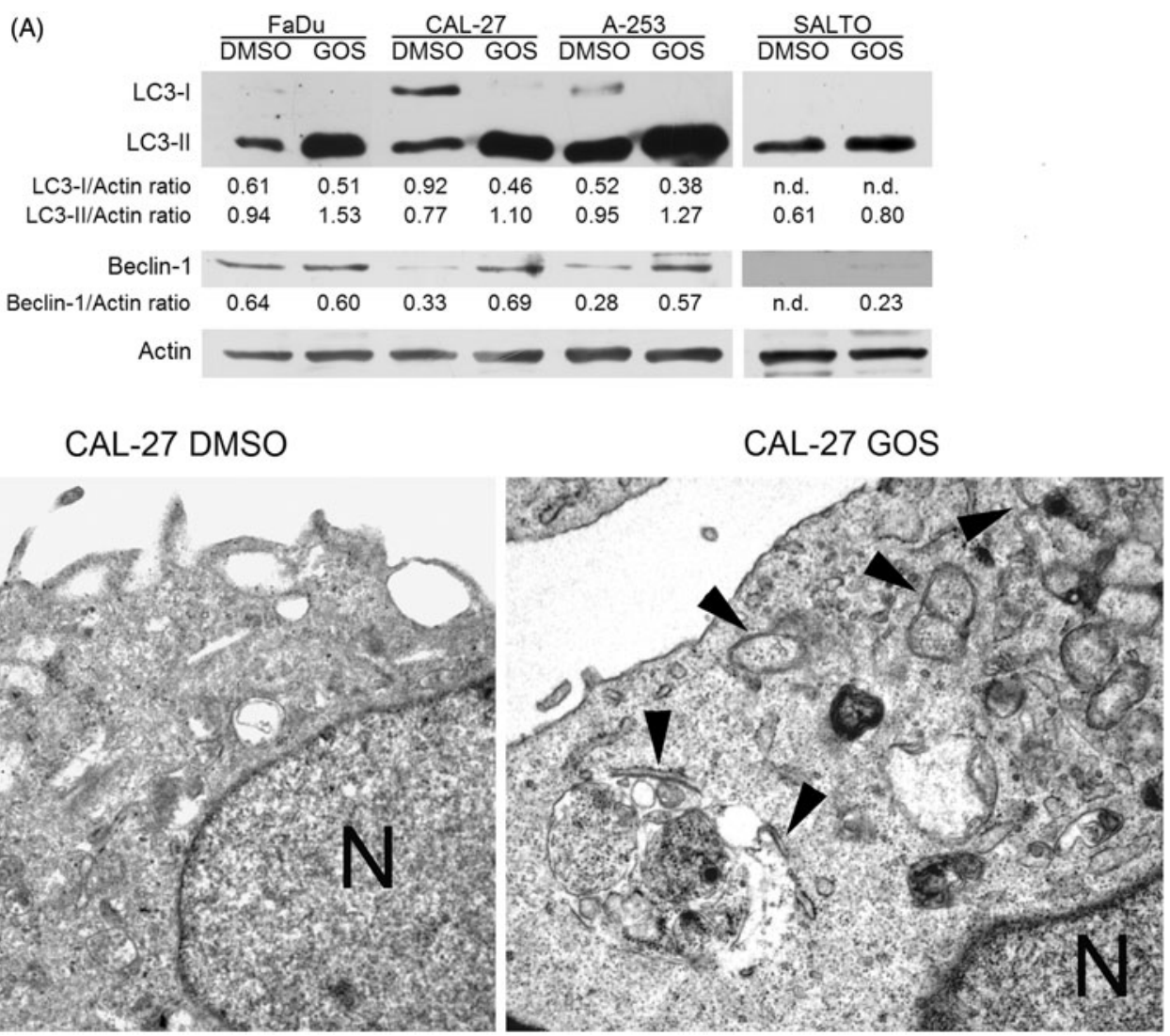

Figure 3. Effect of GOS on the autophagic flux in HNC cells. Panel A: Assessment of the expression of Beclin-1, LC3-I, and LC3-II with Western blotting in HNC cell lines treated with GOS $(20 \mu \mathrm{M})$ or DMSO for 24 or $48 \mathrm{~h}$ (SALTO). Actin was used as an internal control. The intensity of the bands obtained in two independent experiments was quantified using ImageJ software after blot scanning, and the densitometric ratios between Beclin-1 and actin, LC3-I and actin, LC3-II and actin are reported. n.d.= not detected. Panel B: Ultrastructural analysis of autophagy on CAL-27 cells by transmission electron microscopy. CAL-27 cells were treated with GOS at the concentration of $10 \mu \mathrm{M}$ for $24 \mathrm{~h}$ or with DMSO. N: Nucleus. Arrowheads indicate autophagic vacuoles surrounded by double membrane. Original magnification $7900 \times$.

\section{GOS reduces tumor growth in BALB/c mice subcutaneously inoculated with SALTO cells}

To evaluate the in vivo antitumor effect of GOS, groups of $\mathrm{BALB} / \mathrm{c}$ mice (five mice per GOS-group and seven mice per CTR-group) were subcutaneously inoculated with $1 \times 10^{6}$ SALTO cells in the right flank. These mice were treated by intratumoral injection with GOS dissolved in corn oil (GOS) or with the vehicle alone (corn oil, CTR), starting three weeks after tumor cells transplant, one time a week for two weeks. Then mice were treated with oral administration of GOS or corn oil three times a week.

GOS reduced the mean tumor volume compared to control mice one week after the first GOS administration $\left(75.9\right.$ versus $\left.173.3 \mathrm{~mm}^{3} ; p<.05\right)$ and maintained this decrease until five weeks following the beginning of treatment $\left(676.0\right.$ versus $\left.3565.7 \mathrm{~mm}^{3} ; p<.0001\right)$ (Figure 5, panel A). At this stage (eight weeks posttransplant), the corn oil-treated mice were sacrificed because of the excessive size of their tumors, while all GOS-treated mice remained alive. Three GOStreated mice were sacrificed 9,10 , and 14 weeks post-transplant, respectively. Two GOS-treated mice were still alive after 16 weeks post-transplant, with a mean tumor volume of $245.8 \mathrm{~mm}^{3}$. GOS prolonged the median survival time compared to corn oil (14 versus 8 weeks; $p=.0009$ ) (Figure 5, panel B). The risk of SALTO tumor cell growth in the corn oil-treated group was 43.44 relative to the GOS-treated group (Table 3). Overall, our results indicated that GOS specifically interfered with SALTO tumor cell growth.

\section{Discussion}

Polyphenols, a large group of phytochemicals ubiquitously found in plants, exhibit antiinflammatory, antimicrobial, anticancer, and immunomodulatory 


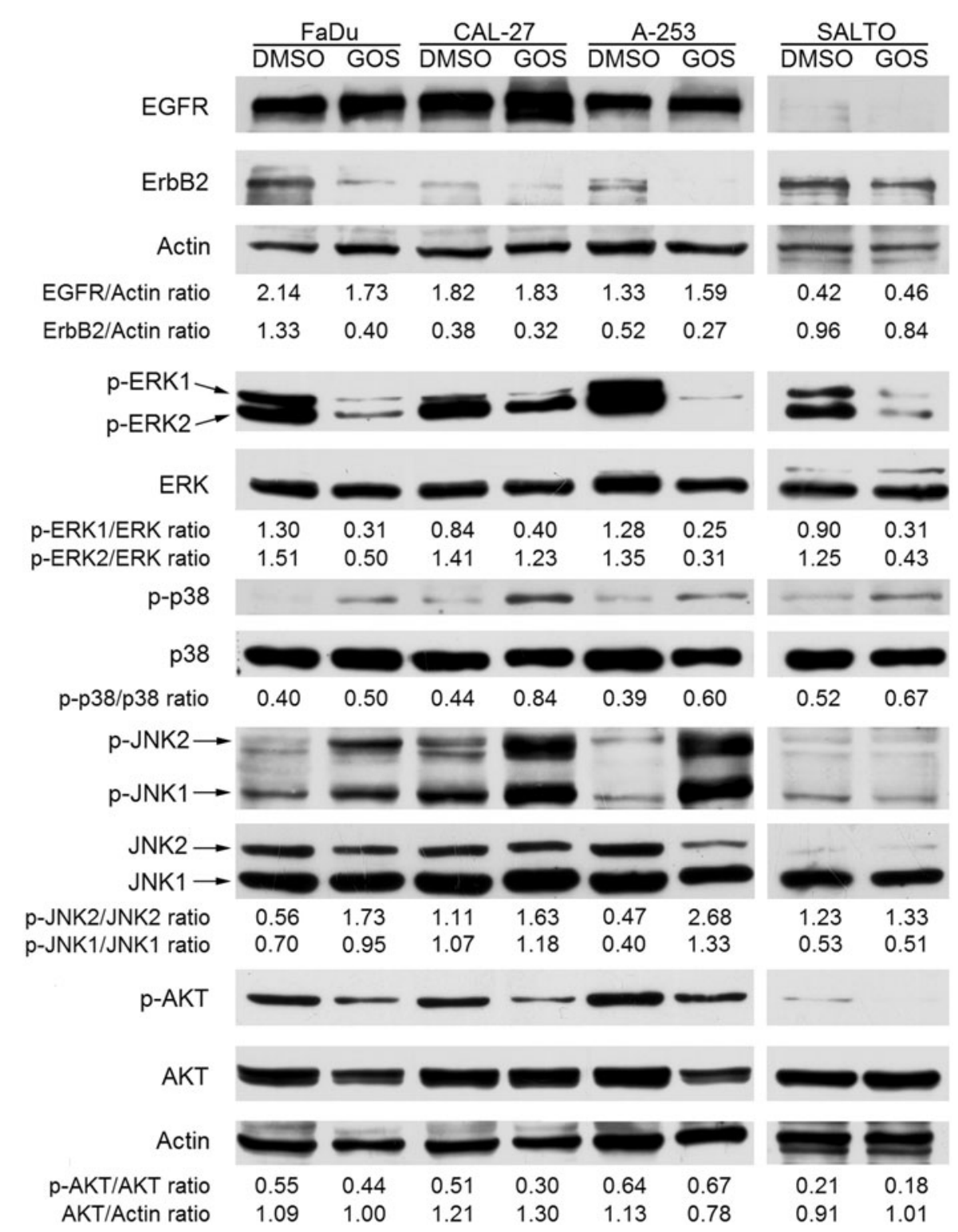

Figure 4. Effect of GOS on the expression and activation of ErbB receptors and pro-survival signaling pathway molecules. Western blotting was performed on HNC cell lines that were treated with GOS $(20 \mu \mathrm{M})$ or DMSO vehicle for 24 or $48 \mathrm{~h}$ (SALTO). The levels of p-ERK1 and p-ERK2 proteins, as well as p-p38 protein, p-JNK1, and p-JNK2 proteins were compared with the total ERK, p38, and JNK1/2 protein levels, respectively. The level of p-AKT was compared with the AKT protein level. Actin was used as an internal control.

activities, and thus are beneficial for human health (Benvenuto et al. 2016).

Racemic Gossypol, (( \pm )-GOS; $( \pm)$-2,2' -bis(8-Formyl1,6,7-trihydroxy-5-isopropyl-3-methylnaphthalene), composed of both (-)-GOS and (+)-GOS, is the naturally occurring polyphenol derived from cotton seeds used in herbal medicines in China (Huang et al. 2006).

The purpose of our study was to evaluate the in vitro and in vivo $( \pm)$-GOS antitumor activity in HNC from different tumor sites (pharynx, tongue, and salivary gland).

To our knowledge, there is only one paper in which the effect of $( \pm)$-GOS on HNC has been investigated
(Oliver et al. 2004). The authors compared the effects of the racemic form and each of the enantiomers of gossypol on cell survival of two squamous carcinoma cell lines only (UM-SCC-6 and UM-SCC-14A). It was reported that (-)-GOS exhibited greater growth inhibition than $( \pm)$-GOS, while $(+)$-GOS had marginal effect on cancer cells survival (Oliver et al. 2004). Other papers have described the effect of (-)-GOS only as single agent or in combination with other therapies employing squamous cell lines only from HNC (Bauer et al. 2005; Wolter et al. 2006; Boehm et al. 2008; Zerp et al. 2009; Imai et al. 2012; Lin et al. 2013b). Taking into account the small amount of results available on the effects of $( \pm)$-GOS on HNC, 

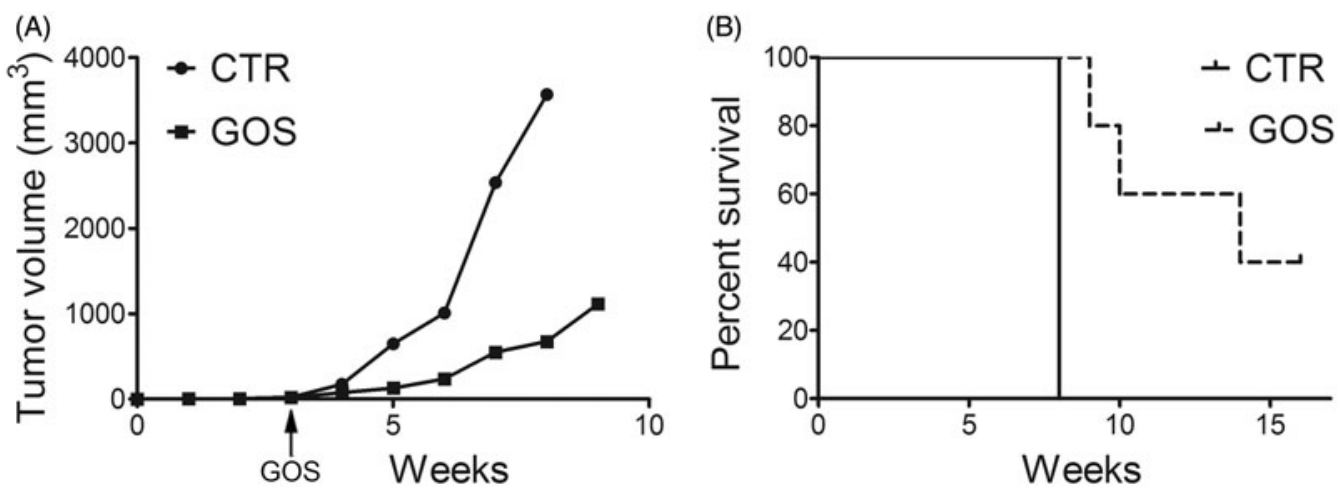

Figure 5. GOS reduced tumor growth and increased the survival in BALB/c mice that were subcutaneously inoculated with SALTO cells. Panel A: Differences in mean tumor volumes between BALB/C mice treated with GOS or corn oil (CTR). Panel B: Differences in the mean survival duration of BALB/c mice treated with GOS or corn oil (CTR). The numbers of inoculated mice are reported in "Materials and methods" section.

Table 3. Analysis of the survival of BALB/c mice after treatment with GOS by the log-rank test (Mantel-Cox).

\begin{tabular}{|c|c|c|c|c|c|c|}
\hline \multirow[b]{2}{*}{ Variable } & \multirow[b]{2}{*}{ Contrast } & \multirow[b]{2}{*}{ Hazard ratio } & \multicolumn{2}{|c|}{$\begin{array}{c}\text { 95\% hazard ratio confi- } \\
\text { dence limits }\end{array}$} & \multirow[b]{2}{*}{$p$ Value } & \multirow[b]{2}{*}{ Median survival (weeks) } \\
\hline & & & Lower & Upper & & \\
\hline Treatment & GOS versus Corn Oil & 43.44 & 4.677 & 403.5 & 0.0009 & 14 versus 8 \\
\hline
\end{tabular}

we sought to extensively investigate the anticancer activity of $( \pm)$-GOS because it is the naturally occurring polyphenolic yellow pigment found in cottonseed products. Conversely, (-)-GOS is the levorotatory isomer of racemic gossypol resolved by various HPLC (high-performance liquid chromatography) methods (Hron et al. 1999).

Thus, the effects of $( \pm)$-GOS on the in vitro and in vivo growth of head and neck cancer cell lines derived from tumors arising from human pharynx ( $\mathrm{FaDu})$, tongue (CAL-27), salivary gland (A-253), and from Neu-overexpressing salivary adenocarcinoma arising in BALB-neuT transgenic male mice (SALTO) and those on signaling pathways aberrantly activated during HNC progression were investigated.

We provide evidence that $( \pm)$-GOS inhibits the proliferation of human HNC cell lines and murine SALTO cells in a dose- and time-dependent manner. Moreover, $( \pm)$-GOS treatment induced a dose-dependent increase in the percentage of cells in the sub-G1 phase and thus induced the activation of apoptosis, as confirmed by the increase of the $\mathrm{Bax} / \mathrm{Bcl}-2$ expression ratio, caspase 3 , and PARP-1 cleavages. In particular, $( \pm)$-GOS activated both the intrinsic and extrinsic apoptotic pathways in human HNC cell lines, as demonstrated by the cleavage of procaspase 8 and 9 . Several studies have previously demonstrated that gossypol is able to activate both the intrinsic and extrinsic pathways of apoptosis in multiple myeloma (Lin et al. 2013a), in human promyelocytic leukemia cells (Hou et al. 2004), in human alveolar lung cancer cells (Chang et al. 2004), and in human colon carcinoma (Wang et al. 2000; Zhang et al. 2003).

In addition, in the human HNC cell lines analyzed, $( \pm)-G O S$ treatment reduced the expression of p53. Accordingly, p53, after the activation of the intrinsic pathways of apoptosis, may be ubiquitinated and degraded or the activation of apoptosis by $( \pm)$-GOS might be due to a transcriptionally independent activities of p53 (Comel et al. 2014).

Beside inducing apoptosis, gossypol is also able to induce autophagy. Previous studies have reported the gossypol-induced activation of autophagy in prostate cancer cells, HeLa cells, and breast adenocarcinoma cells (Gao et al. 2010; Saleem et al. 2012). Our results show that $( \pm)$-GOS decreases the Bcl-2 expression levels in human HNC cell lines analyzed and thus make Beclin-1 available to promote Beclin-1-dependent autophagy. We also demonstrate that $( \pm)$-GOS induces the activation of the autophagic flux in HNC cells, as demonstrated by the increase of the amount of LC3II, by the significant decrease of LC3-I expression and by the increase of the expression of Beclin-1 after $( \pm)$-GOS treatment. Furthermore, we confirmed the activation of autophagic flux in CAL-27 cells employing transmission electron microscopy.

Different signaling transduction pathways are involved in cell growth, autophagy, and apoptosis. Abnormal expression and activation of ErbB receptors are implicated in the development and progression of 
head and neck cancer. Overexpression of ErbB family receptors in the tumor is linked to poor outcome in HNC patients (Sacco \& Worden 2016). In our study, we demonstrate that $( \pm)$-GOS is able to reduce both EGFR and ErbB2 protein expression in HNC cell lines.

Mitogen-activated protein kinases (MAPKs) consist of three family members: extracellular signal-regulated kinases (ERK1/2), c-Jun NH2-terminal kinases (JNK1/2), and p38-MAPKs (p38-MAPK $\alpha$ ) (Wada \& Penninger 2004). ERK1/2 MAPKs are activated in cells following growth stimuli and are the intracellular effectors of ErbB receptors. Hyperactivation of the ERK1/2 signaling pathway frequently occurs in human cancer and is associated with increased cell survival and proliferation (Roberts \& Der 2007). A previous study showed that gossypol is able to inhibit the phosphorylation of ERK1/2 in multiple myeloma cells (Sadahira et al. 2014). Accordingly, we demonstrate that $( \pm)$-GOS is able to inhibit ERK1/2 phosphorylation in human and murine HNC cell lines. JNK1/2 and $\mathrm{p} 38-\mathrm{MAPK} \alpha$ are activated in cells following stress signals and are involved in the regulation of cell proliferation, differentiation, and apoptosis (Wada \& Penninger 2004). A previous study has shown that activation of the JNK pathway by (-)-GOS is essential for the induction of apoptosis in human leukemic cells and head and neck squamous cell carcinoma (Zerp et al. 2009). In addition, another study reported that JNK activation mediates induction of autophagy in head and neck squamous cell carcinoma (Li \& Johnson 2012). Our results are in agreement with these previous findings. Indeed, we demonstrate that $( \pm)$-GOS induces JNK1/2 phosphorylation in human HNC cells, which probably mediates activation of apoptosis and autophagy. Furthermore, it has been shown that p38-MAPK activation is required for TRAIL-induced apoptosis in HNC FaDu cells and for FasL-related apoptosis in oral squamous cancer cells (Kim et al. 2015; Park et al. 2015). Here, we demonstrate that $( \pm)$-GOS is able to increase p38-MAPK $\alpha$ in all HNC cell lines analyzed. Therefore, our data suggest that $( \pm)$-GOS induction of apoptosis is likely mediated by the activation of JNK1/2 and p38MAPKa in HNC cells.

Gossypol also inhibited the phosphorylation and activation of the pro-survival kinase AKT, which induces tumor growth. Previous studies showed that gossypol, employed as single agent and also in combination with valproic acid, was able to inhibit the expression of AKT and phospho-AKT in human prostate cancer cells (Jiang et al. 2009; Zhao et al. 2015).
Several in vivo studies demonstrated that gossypol possesses antitumoral activity in different types of cancer. Ko et al. showed that an intraperitoneal injection of gossypol or gossypol acetic acid (GAA) (5-10 mg/ $\mathrm{kg}$ ) significantly reduced the growth of colorectal carcinoma induced by a subcutaneous injection of COLO205 cells in nude mice (Ko et al. 2007). Moreover, a recent study demonstrated the in vivo antitumoral activity of orally (-)-GOS $(20-40 \mathrm{mg} / \mathrm{kg}$ ) in a mouse model of medulloblastoma (Wang et al. 2015). Several in vivo studies investigated the activity of gossypol in prostate cancer xenograft model in nude mice. A study showed that orally (-)-GOS $(10 \mathrm{mg} / \mathrm{kg})$ enhanced the antitumor activity of X-ray irradiation leading to tumor regression and that oral administration of gossypol was safety without side effects in animals (Xu et al. 2005). Zhang et al. reported that the daily intraperitoneal injection of (-)-GOS $(5-10 \mathrm{mg} / \mathrm{kg})$ for seven days significantly inhibited tumor growth (Zhang et al. 2010). Intralesional injection of $(-)-G O S(15 \mathrm{mg} / \mathrm{kg} / \mathrm{d})$ in the same murine model resulted in suppression of tumor growth (Pang et al. 2011). However, at high doses racemic GOS was shown to be toxic. Indeed, a toxicity study was conducted employing racemic gossypol at an orally dose of $120 \mu \mathrm{mol} / \mathrm{kg}$ daily for five days, for up to three weeks in $\mathrm{BALB} / \mathrm{c}$ female mice (twice the tolerated gossypol dose). Racemic GOS, at this dose, induced weight loss, hepatotoxicity (increased levels of ALT, AST, and regions of hepatocellular necrosis), lymphopenia, and gastrointestinal toxicity (distension of intestines, partial paralitic ileus, diffuse mucosal damage, and necrosis) (Kitada et al. 2008). In addition, gossypol has been shown to cause toxicity and decreases fertility rates in ruminants and nonruminants that ingest it in high concentrations or over a long time (Santana et al. 2015). Toxicity of gossypol derives from the two aldehydic groups of its molecule. However, gossypol represents a potential starting point for the development of antitumor drugs for its anti-proliferative and antitumoral activities. Thus, in order to use gossypol as anticancer drug, some methods have been provided to synthesize gossypol derivatives with reduced toxicity but with the same biological activities (Wang et al. 2009; Yin et al. 2011). Toward this end, gossypol Schiff bases, gossypol ethers, apogossypol series derivatives, gossypolone, gossypol indane, halogenated gossypol, periacetylated gossylic nitriles, periacetylated gossylic imino-lactones, azo-derivatives, hydrazones, and thioderivatives of gossypol have been developed. In addition, glycosilation of gossypol can increase the 
solubility and absorption in a biological system (Yin et al. 2011).

Few papers investigated the in vivo effect of (-)-GOS in murine models of HNC, and none of these evaluated the in vivo effect of $( \pm)$-GOS. (-)-GOS (5-15 mg/kg, daily) was able to suppress head and neck squamous cell carcinoma growth employing an orthotopic xenograft mouse model of aggressive human HNC with high Bcl-xL expression. Gossypol was administered intraperitoneally as a single agent and resulted well tolerated by animals (Wolter et al. 2006). Imai et al. showed that oral administration of (-)-GOS $(10 \mathrm{mg} / \mathrm{kg}$, daily for seven days) in combination with taxotere increased survival of mice bearing head and neck squamous cell carcinoma xenografts (Imai et al. 2012).

Given these observations, we evaluated the in vivo effects of racemic GOS treatment in hampering the growth of transplanted Neu-overexpressing BALBneuT salivary gland adenocarcinoma cells (SALTO) in $\mathrm{BALB} / c$ mice. Racemic GOS has been intratumorally administered for the first time in a syngeneic mouse model of adenocarcinoma of HNC, i.e. adenocarcinoma of the salivary gland. ( \pm )-GOS was intratumorally administered in mice three weeks after a SALTO tumor cell challenge one time a week for two weeks and then mice were treated with oral administration of $( \pm)$-GOS three times a week in order to maintain an effective dose of $( \pm)$-GOS in mice. On the other hand, the intratumoral route of administration should make the compound directly available at the tumor site, allowing for the highest concentration close to tumor cells. Our results demonstrated that ( \pm )-GOS was able to significantly delay tumor growth and to prolong median survival in agreement with our in vitro observations. Mice treated with $( \pm)$-GOS showed a significant decrease in the mean tumor volume compared with control mice one week and until five weeks after the first $( \pm)$-GOS administration and a prolonged median survival time compared to corn oil-treated mice (14 versus 8 weeks; $p=.0009$ ). Considering the survival of $\mathrm{BALB} / \mathrm{c}$ mice, the risk of SALTO tumor cell growth in the corn oil-treated group was 43.44 relative to the $( \pm)$-GOS-treated group. Thus, our results indicated that $( \pm)$-GOS specifically interfered with SALTO tumor cell growth.

Taken together, our results indicate that the treatment of HNC cells with ( \pm )-GOS may be useful in the inhibition of in vivo and in vitro cancer cell growth.

Therefore, the development of therapies targeting Bcl-2 with BH-3 mimetics, as gossypol, could be a promising strategy to enhance the antitumor efficacy of existing standard regimens for HNC patients. The principal metabolites of gossypol naturally occurring after oral administration of racemic gossypol (gossypolone, gossypolonic acid, demethylated gossic acid, and apogossypol) were identified in swine (AbouDonia \& Dieckert 1975). For some of them (i.e. gossypolone), anticancer activity has been demonstrated in vitro (Shelley et al. 1999; Dao et al. 2000). However, further studies are needed to identify the in vivo gossypol secondary metabolites which own anticancer effects and to determine the best concentration of gossypol to be in vivo administered for reaching the effective dose.

\section{Conclusions}

Overall, we provided evidence that racemic gossypol inhibits cell proliferation and induces apoptosis and autophagy of human and mouse head and neck cancer cell lines. In addition, ( \pm )-GOS possesses in vivo antitumor activity, as demonstrated by its ability to interfere with the growth of transplanted mouse salivary gland cancer cells in $\mathrm{BALB} / c$ mice. These findings support further studies on the therapeutic potential of gossypol, as anticancer drug, in combination with standard therapies in head and neck cancer patients.

\section{Acknowledgements}

We thank Mrs K. Bibbey for help in English language editing. SALTO cells were kindly provided by Prof. Federica Cavallo (University of Torino), Prof. Pier Luigi Lollini, and Prof. Patrizia Nanni (University of Bologna). Rosanna Mattera is recipient of the Sapienza $\mathrm{PhD}$ program in Molecular Medicine.

\section{Disclosure statement}

The authors report no conflicts of interest. The authors alone are responsible for the content and writing of the paper.

\section{Funding}

Università di Roma "Sapienza" Ricerche Universitarie [C26A15CX3M].

\section{References}

Abou-Donia MB, Dieckert JW. 1975. Metabolic fate of gossypol: the metabolism of [14-C]gossypol in swine. Toxicol Appl Pharmacol. 31:32-46.

Andrews GA, Xi S, Pomerantz RG, Lin CJ, Gooding WE, Wentzel AL, Wu L, et al. 2004. Mutation of p53 in head and neck squamous cell carcinoma correlates with bcl-2 
expression and increased susceptibility to cisplatininduced apoptosis. Head Neck. 26:870-877.

Barth S, Glick D, Macleod KF. 2010. Autophagy: assays and artifacts. J Pathol. 221:117-124.

Bauer JA, Trask DK, Kumar B, Los G, Castro J, Lee JS, Chen J, et al. 2005. Reversal of cisplatin resistance with a BH3 mimetic, (-)-gossypol, in head and neck cancer cells: role of wild-type p53 and Bcl-xL. Mol Cancer Ther. 4:1096-1104.

Bei R, Guptill V, Masuelli L, Kashmiri SV, Muraro R, Frati L, Schlom J, Kantor J. 1998. The use of a cationic liposome formulation (DOTAP) mixed with a recombinant tumor-associated antigen to induce immune responses and protective immunity in mice. J Immunother. 21:159-169.

Bei R, Pompa G, Vitolo D, Moriconi E, Ciocci L, Quaranta M, Frati L, et al. 2001. Co-localization of multiple ErbB receptors in stratified epithelium of oral squamous cell carcinoma. J Pathol. 195:343-348.

Benvenuto M, Mattera R, Taffera G, Giganti MG, Lido P, Masuelli L, Modesti A, Bei R. 2016. The potential protective effects of polyphenols in asbestos-mediated inflammation and carcinogenesis of mesothelium. Nutrients. 8:pii:E275.

Benvenuto M, Sileri P, Rossi P, Masuelli L, Fantini M, Nanni M, Franceschilli L, et al. 2015. Natural humoral immune response to ribosomal P0 protein in colorectal cancer patients. J Transl Med. 13:101.

Boehm AL, Sen M, Seethala R, Gooding WE, Freilino M, Wong SM, Wang S, et al. 2008. Combined targeting of epidermal growth factor receptor, signal transducer and activator of transcription-3, and $\mathrm{Bcl}-\mathrm{X}(\mathrm{L})$ enhances antitumor effects in squamous cell carcinoma of the head and neck. Mol Pharmacol. 73:1632-1642.

Chang JS, Hsu YL, Kuo PL, Chiang LC, Lin CC. 2004. Upregulation of Fas/Fas ligand-mediated apoptosis by gossypol in an immortalized human alveolar lung cancer cell line. Clin Exp Pharmacol Physiol. 31:716-722.

Comel A, Sorrentino G, Capaci V, Del Sal G. 2014. The cytoplasmic side of p53's oncosuppressive activities. FEBS Lett. 588:2600-2609.

Courtois SJ, Woodworth CD, Degreef H, Garmyn M. 1997. Early ultraviolet B-induced G1 arrest and suppression of the malignant phenotype by wild-type p53 in human squamous cell carcinoma cells. Exp Cell Res. 233:135-144.

Dao VT, Gaspard C, Mayer M, Werner GH, Nguyen SN, Michelot RJ. 2000. Synthesis and cytotoxicity of gossypol related compounds. Eur J Med Chem. 35:805-813.

Delbridge AR, Strasser A. 2015. The BCL-2 protein family, BH3-mimetics and cancer therapy. Cell Death Differ. 22:1071-1080.

FAO/WHO/UNICEF. 1972. Protein Advisory Group of the United Nations, PAG Guideline No.4, "Preparation of Edible Cottonseed Protein Concentrate." New York: $\mathrm{FAO} / \mathrm{WHO} / \mathrm{UNICEF}$.

Ferlay J, Soerjomataram I, Dikshit R, Eser S, Mathers C, Rebelo M, Parkin DM, et al. 2015. Cancer incidence and mortality worldwide: sources, methods and major patterns in GLOBOCAN 2012. Int J Cancer. 136:E359-E386.

Flack MR, Pyle RG, Mullen NM, Lorenzo B, Wu YW, Knazek RA, Nisula BC, Reidenberg MM. 1993. Oral gossypol in the treatment of metastatic adrenal cancer. J Clin Endocrinol Metab. 76:1019-1024.

Food and Drug Administration (FDA). 1974. Food drug cosmetic law. 56, 518.94, 172.894.

Frajese GV, Benvenuto M, Fantini M, Ambrosin E, Sacchetti P, Masuelli L, Giganti MG, et al. 2016. Potassium increases the antitumor effects of ascorbic acid in breast cancer cell lines in vitro. Oncol Lett. 11:4224-4234.

Gao P, Bauvy C, Souquère S, Tonelli G, Liu L, Zhu Y, Qiao Z, et al. 2010. The Bcl-2 homology domain 3 mimetic gossypol induces both Beclin 1-dependent and Beclin 1-independent cytoprotective autophagy in cancer cells. J Biol Chem. 285:25570-25581.

Hata AN, Engelman JA, Faber AC. 2015. The BCL2 family: key mediators of the apoptotic response to targeted anticancer therapeutics. Cancer Discov. 5:475-487.

Hou DX, Uto $\mathrm{T}$, Tong $\mathrm{X}$, Takeshita $\mathrm{T}$, Tanigawa $\mathrm{S}$, Imamura I, Ose T, Fujii M. 2004. Involvement of reactive oxygen species-independent mitochondrial pathway in gossypol-induced apoptosis. Arch Biochem Biophys. 428:179-187.

Hron RJ, Kim HL, Calhoun MC, Fisher GS. 1999. Determination of $(+)-,(-)-$, and total gossypol in cottonseed by high-performance liquid chromatography. J Am Oil Chem Soc. 76:1351-1355.

Huang YW, Wang LS, Chang HL, Ye W, Sugimoto Y, Dowd MK, Wan PJ, Lin YC. 2006. Effects of serum on (-)-gossypol-suppressed growth in human prostate cancer cells. Anticancer Res. 26:3613-3620.

Imai A, Zeitlin BD, Visioli F, Dong Z, Zhang Z, Krishnamurthy S, Light E, et al. 2012. Metronomic dosing of $\mathrm{BH} 3$ mimetic small molecule yields robust antiangiogenic and antitumor effects. Cancer Res. 72:716-725.

Jiang J, Ye W, Lin YC. 2009. Gossypol inhibits the growth of MAT-LyLu prostate cancer cells by modulation of TGFbeta/Akt signaling. Int J Mol Med. 24:69-75.

Kang R, Zeh HJ, Lotze MT, Tang D. 2011. The Beclin 1 network regulates autophagy and apoptosis. Cell Death Differ. 18:571-580.

Kim JS, Oh D, Yim MJ, Park JJ, Kang KR, Cho IA, Moon SM, et al. 2015. Berberine induces FasL-related apoptosis through p38 activation in $\mathrm{KB}$ human oral cancer cells. Oncol Rep. 33:1775-1782.

Kitada S, Kress CL, Krajewska M, Jia L, Pellecchia M, Reed JC. 2008. Bcl-2 antagonist apogossypol (NSC736630) displays single-agent activity in Bcl-2transgenic mice and has superior efficacy with less toxicity compared with gossypol (NSC19048). Blood. 111:3211-3219.

Ko CH, Shen SC, Yang LY, Lin CW, Chen YC. 2007. Gossypol reduction of tumor growth through ROSdependent mitochondria pathway in human colorectal carcinoma cells. Int J Cancer. 121:1670-1679.

Li C, Johnson DE. 2012. Bortezomib induces autophagy in head and neck squamous cell carcinoma cells via JNK activation. Cancer Lett. 314:102-107.

Lian J, Karnak D, Xu L. 2010. The Bcl-2-Beclin 1 interaction in (-)-gossypol-induced autophagy versus apoptosis in prostate cancer cells. Autophagy. 6:1201-1203.

Lin J, Wu Y, Yang D, Zhao Y. 2013a. Induction of apoptosis and antitumor effects of a small molecule inhibitor of 
Bcl-2 and Bcl-xl, gossypol acetate, in multiple myeloma in vitro and in vivo. Oncol Rep. 30:731-738.

Lin YL, Yuksel Durmaz Y, Nör JE, El-Sayed ME. 2013b. Synergistic combination of small molecule inhibitor and RNA interference against antiapoptotic Bcl-2 protein in head and neck cancer cells. Mol Pharm. 10:2730-2738.

Maiuri MC, Criollo A, Tasdemir E, Vicencio JM, Tajeddine N, Hickman JA, Geneste O, Kroemer G. 2007. BH3-only proteins and $\mathrm{BH} 3$ mimetics induce autophagy by competitively disrupting the interaction between Beclin 1 and $\mathrm{Bcl}-2 / \mathrm{Bcl}-\mathrm{X}(\mathrm{L})$. Autophagy. 3:374-376.

Marquez RT, Liang X. 2012. Bcl-2:Beclin 1 complex: multiple, mechanisms regulating autophagy/apoptosis toggle switch. Am J Cancer Res. 2:214-221.

Masuelli L, Bei R, Sacchetti P, Scappaticci I, Francalanci P, Albonici L, Coletti A, et al. 2003. Beta-catenin accumulates in intercalated disks of hypertrophic cardiomyopathic hearts. Cardiovasc Res. 60:376-387.

Masuelli L, Budillon A, Marzocchella L, Mrozek MA, Vitolo D, Di Gennaro E, Losito S, et al. $2012 \mathrm{~b}$. Caveolin-1 overexpression is associated with simultaneous abnormal expression of the E-cadherin $/ \alpha-\beta$ catenins complex and multiple ErbB receptors and with lymph nodes metastasis in head and neck squamous cell carcinomas. J Cell Physiol. 227:3344-3353.

Masuelli L, Di Stefano E, Fantini M, Mattera R, Benvenuto M, Marzocchella L, Sacchetti P, et al. 2014a. Resveratrol potentiates the in vitro and in vivo antitumoral effects of curcumin in head and neck carcinomas. Oncotarget. 5:10745-10762.

Masuelli L, Fantini M, Benvenuto M, Sacchetti P, Giganti MG, Tresoldi I, Lido P, Lista F, Cavallo F, Nanni P, et al. 2014b. Intratumoral delivery of recombinant vaccinia virus encoding for ErbB2/Neu inhibits the growth of salivary gland carcinoma cells. J Transl Med. 12:122.

Masuelli L, Marzocchella L, Focaccetti C, Lista F, Nardi A, Scardino A, Mattei M, et al. 2010. Local delivery of recombinant vaccinia virus encoding for neu counteracts growth of mammary tumors more efficiently than systemic delivery in neu transgenic mice. Cancer Immunol Immunother. 59:1247-1258.

Masuelli L, Marzocchella L, Focaccetti C, Tresoldi I, Palumbo C, Izzi V, Benvenuto M, et al. 2012a. Resveratrol and diallyl disulfide enhance curcumininduced sarcoma cell apoptosis. Front Biosci. 17:498-508.

Masuelli L, Pantanella F, La Regina G, Benvenuto M, Fantini M, Mattera R, Di Stefano E, et al. 2016. Violacein, an indole-derived purple-colored natural pigment produced by Janthinobacterium lividum, inhibits the growth of head and neck carcinoma cell lines both in vitro and in vivo. Tumour Biol. 37:3705-3717.

Meng Y, Tang W, Dai Y, Wu X, Liu M, Ji Q, Ji M, et al. 2008. Natural BH3 mimetic (-)-gossypol chemosensitizes human prostate cancer via $\mathrm{Bcl}-\mathrm{xL}$ inhibition accompanied by increase of Puma and Noxa. Mol Cancer Ther. 7:2192-2202.

Mizushima N, Yoshimori T. 2007. How to interpret LC3 immunoblotting. Autophagy. 3:542-545.

Oliver CL, Bauer JA, Wolter KG, Ubell ML, Narayan A, O'Connell KM, Fisher SG, et al. 2004. In vitro effects of the $\mathrm{BH} 3$ mimetic, (-)-gossypol, on head and neck squamous cell carcinoma cells. Clin Cancer Res. 10:7757-7763.

Pang X, Wu Y, Wu Y, Lu B, Chen J, Wang J, Yi Z, et al. 2011. (-)-Gossypol suppresses the growth of human prostate cancer xenografts via modulating VEGF signaling-mediated angiogenesis. Mol Cancer Ther. 10:795-805.

Pannellini T, Spadaro M, Di Carlo E, Ambrosino E, Iezzi M, Amici A, Lollini PL, et al. 2006. Timely DNA vaccine combined with systemic IL-12 prevents parotid carcinomas before a dominant-negative p53 makes their growth independent of HER-2/neu expression. J Immunol. 176:7695-7703.

Park MR, Kim SG, Cho IA, Oh D, Kang KR, Lee SY, Moon SM, et al. 2015. Licochalcone-A induces intrinsic and extrinsic apoptosis via ERK1/2 and p38 phosphorylation-mediated TRAIL expression in head and neck squamous carcinoma $\mathrm{FaDu}$ cells. Food Chem Toxicol. 77:34-43.

Reiss M, Brash DE, Muñoz-Antonia T, Simon JA, Ziegler A, Vellucci VF, Zhou ZL. 1992. Status of the p53 tumor suppressor gene in human squamous carcinoma cell lines. Oncol Res. 4:349-357.

Roberts PJ, Der CJ. 2007. Targeting the Raf-MEK-ERK mitogen-activated protein kinase cascade for the treatment of cancer. Oncogene. 26:3291-3310.

Sacco AG, Worden FP. 2016. Molecularly targeted therapy for the treatment of head and neck cancer: a review of the ErbB family inhibitors. Onco Targets Ther. 9:1927-1943.

Sadahira K, Sagawa M, Nakazato T, Uchida H, Ikeda Y, Okamoto S, Nakajima H, Kizaki M. 2014. Gossypol induces apoptosis in multiple myeloma cells by inhibition of interleukin-6 signaling and $\mathrm{Bcl}-2 / \mathrm{Mcl}-1$ pathway. Int $\mathrm{J}$ Oncol. 45:2278-2286.

Saleem A, Dvorzhinski D, Santanam U, Mathew R, Bray K, Stein M, White E, DiPaola RS. 2012. Effect of dual inhibition of apoptosis and autophagy in prostate cancer. Prostate. 72:1374-1381.

Santana AT, Guelfi M, Medeiros HC, Tavares MA, Bizerra PF, Mingatto FE. 2015. Mechanisms involved in reproductive damage caused by gossypol in rats and protective effects of vitamin E. Biol Res. 48:43.

Schelman WR, Mohammed TA, Traynor AM, Kolesar JM, Marnocha RM, Eickhoff J, Keppen M, et al. 2014. A phase I study of AT-101 with cisplatin and etoposide in patients with advanced solid tumors with an expanded cohort in extensive-stage small cell lung cancer. Invest New Drugs. 32:295-302.

Shelley MD, Hartley L, Fish RG, Groundwater P, Morgan JJ, Mort D, Mason M, Evans A. 1999. Stereo-specific cytotoxic effects of gossypol enantiomers and gossypolone in tumour cell lines. Cancer Lett. 135:171-180.

Sinha S, Levine B. 2008. The autophagy effector Beclin 1. A novel BH3-only protein. Oncogene. 27:S137-S148.

Sonpavde G, Matveev V, Burke JM, Caton JR, Fleming MT, Hutson TE, Galsky MD, et al. 2012. Randomized phase II trial of docetaxel plus prednisone in combination with placebo or AT-101, an oral small molecule Bcl-2 family antagonist, as first-line therapy for metastatic castrationresistant prostate cancer. Ann Oncol. 23:1803-1808.

Stein RC, Joseph AE, Matlin S, Cunningham DC, Ford HT, Coombes RC. 1992. A preliminary clinical study of 
gossypol in advanced human cancer. Cancer Chemother Pharmacol. 30:480-482.

Sunilkumar G, Campbell LM, Puckhaber L, Stipanovic RD, Rathore KS. 2006. Engineering cottonseed for use in human nutrition by tissue-specific reduction of toxic gossypol. Proc Natl Acad Sci USA. 103:18054-18059.

Swiecicki PL, Bellile E, Sacco AG, Pearson AT, Taylor JM, Jackson TL, Chepeha DB, et al. 2016. A phase II trial of the BCL-2 homolog domain 3 mimetic AT-101 in combination with docetaxel for recurrent, locally advanced, or metastatic head and neck cancer. Invest New Drugs. 34:481-489.

van Poznak C, Seidman AD, Reidenberg MM, Moasser MM, Sklarin N, Van Zee K, Borgen P, et al. 2001. Oral gossypol in the treatment of patients with refractory metastatic breast cancer: a phase I/II clinical trial. Breast Cancer Res Treat. 66:239-248.

Vela L, Gonzalo O, Naval J, Marzo I. 2013. Direct interaction of $\mathrm{Bax}$ and Bak proteins with Bcl-2 homology domain 3 (BH3)-only proteins in living cells revealed by fluorescence complementation. J Biol Chem. 288:4935-4946.

Wada T, Penninger JM. 2004. Mitogen-activated protein kinases in apoptosis regulation. Oncogene. 23:2838-2849.

Wang J, Peng Y, Liu Y, Yang J, Huang M, Tan W. 2015. AT-101 inhibits hedgehog pathway activity and cancer growth. Cancer Chemother Pharmacol. 76:461-469.

Wang X, Howell CP, Chen F, Yin J, Jiang Y. 2009. Gossypol-a polyphenolic compound from cotton plant. Adv Food Nutr Res. 58:215-263.

Wang X, Wang J, Wong SC, Chow LS, Nicholls JM, Wong YC, Liu Y, et al. 2000. Cytotoxic effect of gossypol on colon carcinoma cells. Life Sci. 67:2663-2671.

Wolter KG, Wang SJ, Henson BS, Wang S, Griffith KA, Kumar B, Chen J, et al. 2006. (-)-Gossypol inhibits growth and promotes apoptosis of human head and neck squamous cell carcinoma in vivo. Neoplasia. 8:163-172.

Xie X, Clausen OP, De Angelis P, Boysen M. 1999. The prognostic value of spontaneous apoptosis, Bax, bcl-2, and p53 in oral squamous cell carcinoma of the tongue. Cancer. 86:913-920.

Xu L, Yang D, Wang S, Tang W, Liu M, Davis M, Chen J, et al. 2005. (-)-Gossypol enhances response to radiation therapy and results in tumor regression of human prostate cancer. Mol Cancer Ther. 4:197-205.

Yin J, Jin L, Chen F, Wang X, Kitaygorodskiy A, Jiang Y. 2011. Novel O-glycosidic gossypol isomers and their bioactivities. Carbohydr Res. 346:2070-2074.

Yu Y, Dong W, Li X, Yu E, Zhou X, Li S. 2003. Significance of $\mathrm{c}-\mathrm{Myc}$ and $\mathrm{Bcl}-2$ protein expression in nasopharyngeal carcinoma. Arch Otolaryngol Head Neck Surg. 129:1322-1326.

Zhang M, Liu H, Guo R, Ling Y, Wu X, Li B, Roller PP, et al. 2003. Molecular mechanism of gossypol-induced cell growth inhibition and cell death of HT-29 human colon carcinoma cells. Biochem Pharmacol. 66:93-103.

Zhang XQ, Huang XF, Mu SJ, An QX, Xia AJ, Chen R, $\mathrm{Wu}$ DC. 2010. Inhibition of proliferation of prostate cancer cell line, PC-3, in vitro and in vivo using (-)-gossypol. Asian J Androl. 12:390-399.

Zhao GX, Xu LH, Pan H, Lin QR, Huang MY, Cai JY, Ouyang DY, He XH. 2015. The BH3-mimetic gossypol and noncytotoxic doses of valproic acid induce apoptosis by suppressing cyclin-A2/Akt/FOXO3a signaling. Oncotarget. 6:38952-38966.

Zerp SF, Stoter R, Kuipers G, Yang D, Lippman ME, van Blitterswijk WJ, Bartelink H, et al. 2009. AT-101, a small molecule inhibitor of anti-apoptotic Bcl-2 family members, activates the SAPK/JNK pathway and enhances radiation-induced apoptosis. Radiat Oncol. 4:47. 